\title{
Will Noah's Ark depart from the Amazon River floodplains?
}

\author{
I. M. Madaleno \\ Portuguese Tropical Research Institute, Lisbon
}

\begin{abstract}
The Amazon rainforest constitutes the widest green spot on Earth. However, man's desire to exploit the incredible ground and underground natural resources is provoking destruction as deforestation pathways widen, rivers fall short on water and climate changes. Research undertaken in Brazil was aimed at the collection of local food, knowledge and practises, a quest intended to recover ancestral ecological experiences on a virtual Noah's Ark before the announced death of this Garden of Eden. This paper contrasts traditional agro-pastoral and extractive practises gathered among Caboclos along the Amazon River banks and floodplains with modern and capital-intensive agribusinesses settled alongside the BR-163 motorway. This contribution argues that ancestral environmentally friendly farming practises should be protected, both because they preserve the remainder of the woodland and its immense biogenetic richness and the Amazon Basin Rivers and their bounteous potential for life. Successful and long sustained cultivation on fertile riverbank alluvial soils, rebuilt by floods year after year, possesses a favourable demonstrative effect, valuable for other tropical sites, constituting a good array of best practises towards sustainable development.
\end{abstract}

Keywords: Amazon rainforest, floodplains, BR-163, sustainable development.

\section{Introduction}

The Legal Brazilian Amazon (LBA) was first established in 1953 (Law 1 806) and recently redrawn by force of the 2007 Complementary Law ${ }^{\circ} 124$. It comprises 8.5 Brazilian states, located west of $44^{\circ} \mathrm{W}$ of Greenwich. The LBA totals $5,088,688 \mathrm{~km}^{2}$, about $60 \%$ of Brazil, where demographic growth after the Second World War reached 518\%, well above the national average of $254 \%$ (see 
Table 1). The Amazon River is both the Amazon Rainforest spinal column and a shady labyrinth of rivers and igarapés that penetrate the jungle, handy fluvial roads used by local peasants (Caboclos) canoes and barges, in order to get to the shacks they inhabit during dry cropping season. On the floodplains the subsistence farm households still live in harmony with nature, because the forest, the alluvial soils and the rivers constitute food sources and income. Caboclos are multi-functional and multi-local, displacing themselves and their belongings from high ground to the floodplains over the year in sheer respect for the rhythm of the Amazon River waters. Illegal and predatory timber exploitation, cattleranching, mining and farming ventures, however, have been destroying considerable portions of rainforest over the years, a process enhanced recently with heat-resistant GMS soybean farms, chained to poultry and pig industries and now to biofuel production, which in a decade have deforested the Brazilian Pará State.

Table 1: Legal Brazilian Amazon demographic evolution $(1,000$ inhabitants).

\begin{tabular}{|l|r|r|r|r|r|}
\hline $\begin{array}{c}\text { Brazilian } \\
\text { Federation } \\
\text { Units }\end{array}$ & $\mathbf{1 9 5 0}$ & $\mathbf{1 9 7 0}$ & $\mathbf{1 9 9 1}$ & $\mathbf{2 0 0 7}$ & $\begin{array}{c}\text { Growth } \\
\mathbf{1 9 5 0 - 2 0 0 7} \\
\mathbf{\%}\end{array}$ \\
\hline Acre & 114 & 215 & 418 & 654 & 474 \\
\hline Amazonas & 514 & 955 & 2,103 & 3,168 & 516 \\
\hline Amapá & 34 & 114 & 289 & 585 & 1,620 \\
\hline Maranhão & 1,583 & 2,993 & 4,930 & 6,118 & 286 \\
\hline Mato Grosso & 213 & 600 & 2,027 & 2,854 & 1,240 \\
\hline Pará & 1,123 & 2,167 & 4,950 & 7,071 & 530 \\
\hline Rondónia & 37 & 111 & 1,133 & 1,454 & 3,830 \\
\hline Roraima & 18 & 41 & 218 & 394 & 2,089 \\
\hline Tocantins & 184 & 521 & 920 & 1,248 & 578 \\
\hline $\begin{array}{l}\text { Legal } \\
\text { Brazilian } \\
\text { Amazon }\end{array}$ & 3,820 & 7,717 & 16,988 & 23,546 & 518 \\
\hline
\end{tabular}

Source: MMA [3]

\section{Amazon rainforest recent history}

The Amazon River and its tributaries constitute the widest network of navigable waters on Earth, totalling $20,000 \mathrm{~km}$ in the rainy season. During the Second World War most of Brazil was cut off from northern Amazon cities, such as Manaus and Belém, as a consequence of the serious constrictions to navigation over Southern Atlantic waters due to the conflict. Hence, public policies devised in the post-war period targeted the construction of a terrestrial network of roads, which could connect the southern and central Brazilian metropolis (such as $\mathrm{S}$. Paulo, Rio de Janeiro and, after 1960, Brasilia the new capital city) to the Amazon riverside cities and towns (see photo, Fig. 1).

New access roads brought an end to the isolation of the Amazon Rainforest and facilitated both public capitalised enterprises and spontaneous colonisation waves, either populist or corporative. In the pre-integration period colonists had been restricted to the banks of the navigable rivers, particularly the Amazon 
River meanders and their numerous fluvial islands, but the new settlers moving by these terrestrial motorways easily deepened the rainforest through secondary roads, deforesting for farming, mining, cattle raising and logging. On this final frontier new towns rapidly blossomed, a state-led process in the 1970s, when rural towns, called "ruropolis" popped over the Trans-Amazon Road, furthered with mineral poles during the 1980s and boom urban centres from the mid 1990s to the present.

Ryder and Brown [1] defined frontier as relatively static border zones located between neighbouring states or dynamic peripheral regions in the throes of absorption into the national and global economies. The last is unambiguously the case with the selected study areas. Significant colonisation targeted crossroads BR-163 (Cuiabá-Santarém) and BR-230 (the Trans-Amazon) during the first governmental colonisation programmes (1970-74). Created in February 1972, it was named the Itaituba Integrated Colonisation Plan and it included two urban centres - Itaituba and Ruropolis President Medici - the first built-up area by the side of the BR-163 and the second one located next to the Trans-Amazon aimed at settling 750 households on 100 hectare plots [2].

Colonisation programmes were replaced with more aggressive, and sometimes gigantic, farming and mineral pole settlements during the 1980s when Brazilian foreign debt rose to an unbearable level and national economic policies targeted commodity exports to more developed countries. The growth of farming frontiers increased, aimed at rice, fruit culture and corn production at first, and soybeans by the end of that decade. Nowadays, $70.7 \%$ of the Amazon Region farming plots are larger than 10,000 hectares. Heat resistant soy seeds were introduced in 1988 in Roraima state, the following year in Tocantins, and in 1998 they had reached Pará. Pioneers from Southern Brazil have invaded the jungle, either subsidised or credit favoured by weighty enterprises such as Cargill and the Maggi Group.

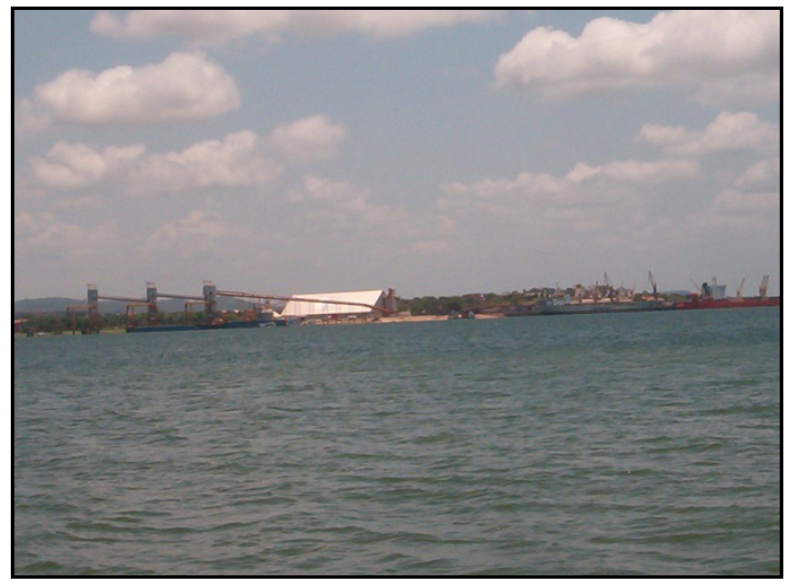

Figure 1: The Amazon River near the city of Santarém, Pará, with a view to the Cargill soybeans terminal (2006). 


\section{Contrasting developing options}

Technocrats involved in remote planning have lost the notion of scale when conceiving rainforest connections and while networking the immense LBA space [3], a gigantic amphitheatre of table hills and over two million square kilometres of planes surrounded by the Guyana Plateau (N), the Andean Mountains (W) and the Brazilian Plateau (S), a portion of which is less than 10 metres high (the lowlands or várzea) and is mostly fluvial islands. Disposed on a zoned area parallel to the Equatorial line, the LBA has a unique geomorphology and it is covered with a quite characteristic dense forest, considered the richest of all Earth's ecosystems, bordered by cerrados, a savannah type of vegetation [4].

Rainforest vulnerability is due to the thin soil systems that support the trees, whereas a wide range of life forms are fed by the thick layer of dead leaves, branches and animal corpses slowly decomposing underneath the tall wooden giants, subject to high temperature and humidity conditions. When the trees are cut and heavy machinery revolves the soil, death that supported dense tropical rainforest species is washed away to the rivers and new life has to be fed by considerable amounts of chemical fertilisers in order to nourish the pastures and food produce. About 20\% of deforested land has been abandoned a couple of years after deforestation and has been degraded in less than ten years along the Belém-Brasilia Federal Road, BR-010 [5].

\subsection{The ancestral riverine Amazon}

In 1541-42, Father Gaspar de Carvajal, who accompanied the Spanish explorer and conqueror Francisco Orellana, wrote an amazing portrait of the peoples and landscapes he saw alongside the Amazon River during this first European journey [6]. The existence of densely populated islands, where the Indians grew cassava and maize, was later corroborated by reports from Father Laureano de la Cruz (1651). During the dry season, in 2006 and 2007, the Portuguese Tropical Research Institute conducted two missions to the Lower Amazon municipality of Santarém, Pará state, located within the LBA.

The fieldwork included fifty in-depth interviews with four categories of informants: i) regional and local authorities, intended to get a picture of current development options; ii) judges, lawmakers, technicians and university experts, whose insight contribution was decisive in understanding the environmental status and conflicting situations of the LBA and the municipality of Santarém, in particular; iii) artisans, traders and service providers from the urban realm were also questioned in order to obtain a comprehensive understanding of urban livelihoods in a remote Amazonian town and an examination of their perception of the rural realm; iv) finally, the bulk of the sample targeted 32 households from four Lower Amazon River floodplain settings: Nova Island (see Fig. 2), Maicá and Ituqui Islands (Fig. 3) and Igarapé-Açu (Great Channel in the Tupi language).

All households have been examined during the dry season (from July to December) at their shack used during the cropping period, as during the rainy 
season they displace their belongings to safe upland terra firme (located above 10 metres high). This is because the water level rises about 7 metres during the floods, with total annual precipitation averaging between 1,750 and 2,000 millimetres in the study area. With two exceptions of male farmers living on high ground year round and travelling to the floodplains every day, during the cropping period, the remainder of interviewed households spent about half the year on the fluvial islands and Igarapé-Açu margins, cleaning-up the soil, sowing, planting, tending both subsistence (10 to 60\%) and cash crops, harvesting melons, watermelons, corn, beans, cassava, picking up bananas and papayas, and growing a dozen different horticulture species, some of them local seeds, in order to sell the produce in the nearby city markets. Farming tasks are developed in a co-operative manner within the family.
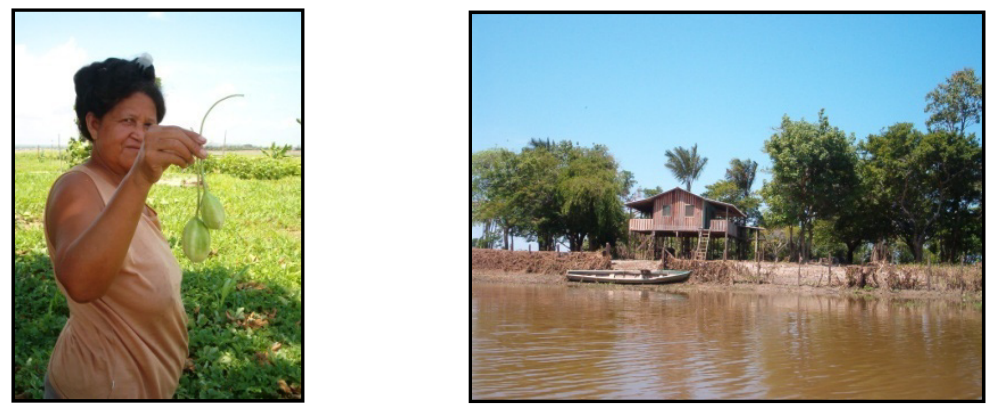

Figure 2: Cabocla with maxixe (Cucumis sativus) on Nova Island, a Santarém fluvial island and typical wooden house from IgarapéAçu (2007).

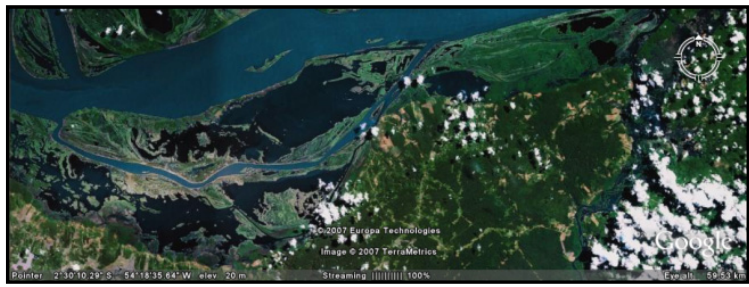

Figure 3: $\quad$ Satellite imagery of Ituqui Island, Amazon River Southern margin (2007).

Results have shown that organic farming practises persist within the Caboclo communities, with people engaged in traditional horticulture and animal farming activities. Vegetables, melons and watermelons are irrigated (if income allows it using motorized pumps), whilst the subsistence crop cassava is not, usually being tended on higher ground. Organic fertilisers, such as tree leftovers ("estrume de pau") and a rich mulching of manure amassed with straw to form powerful compost, are the universal fertilisers in the floodplains (see Table 2). The Caboclos consider these to be identical ways of feeding the soil to the ones they 
observe in the superficial jungle soil layers and forests they exploit for food and medicine (barks, seeds, leaves and fruits). Even though more than half of the Caboclo population interviewed fertilises the alluvial soil, particularly on Ituqui Island, the largest in surface area (about 20,000 hectares), where two melon, watermelon and tomato crops are grown per dry season, the survey has shown that some crops survive solely on rich alluvial deposits; the number of plot owners that use chemical fertilisers was rather small and it has been registered only in two island settings - Nova and Ituqui.

Table 2: $\quad$ Soil fertilisation in the Amazon River floodplains.

\begin{tabular}{|l|c|c|c|c|c|}
\hline \multicolumn{1}{|c|}{ Type of fertiliser } & $\begin{array}{c}\text { Nova } \\
\text { Island }\end{array}$ & $\begin{array}{c}\text { Igarapé- } \\
\text { Açu }\end{array}$ & $\begin{array}{c}\text { Maicá } \\
\text { Island }\end{array}$ & $\begin{array}{c}\text { Ituqui } \\
\text { Island }\end{array}$ & $\begin{array}{c}\text { Average/ } \\
\text { Total N }\end{array}$ \\
\hline Straw and manure mulching & $70 \%$ & $50 \%$ & $50 \%$ & $70 \%$ & $60 \%$ \\
\hline Tree leftovers & $20 \%$ & $50 \%$ & $100 \%$ & $100 \%$ & $67.5 \%$ \\
\hline Alluvial deposits & $100 \%$ & $100 \%$ & $100 \%$ & $100 \%$ & $100 \%$ \\
\hline Chemicals & $10 \%$ & 0 & 0 & $10 \%$ & $5 \%$ \\
\hline $\mathrm{N}^{\circ}$ of household interviews & 10 & 2 & 10 & 10 & 32 \\
\hline Number of smallholders & 30 & 100 & 100 & 800 & 1030 \\
\hline
\end{tabular}

Source: Santarém municipality and 2006-07 household surveys

The outlook of Caboclo farmed plots quite chaotic, with fruit trees growing here and there, persistently surviving the seasonal floods. The plot size can add up to 20 hectares per household, yet they usually only farm about 2 hectares located alongside the river banks for that option facilitates manual irrigation. Interior areas are forest covered and reserved for cattle, left free to roam. Fencing is rare and illegal. Built-up wooden houses (see fig. 2) have a linear layout on top of riverbanks. Both women and men fish at Ituqui and Maicá Islands, but not in the remainder of the surveyed settings where the task is dominantly male. The common link between these communities is their organization in associations, ranging from smallholders on Nova Island to fish and farm producers in Ituqui. Using these associations to control informal seasonal farmers, the Brazilian government has managed to ensure they respect the fish breeding period (mid November to mid March), whilst paying any association registered as Caboclo a minimum wage for the length of four months.

Landownership is a contended issue with INCRA (National Colonisation and Agrarian Reform Institute) for very few floodplain lands have been registered as individual property. Currently, the Brazilian government is considering the possibility of communal ownership concession to the Caboclo communities, to be delivered with water and electricity services, a highly unpopular measure among the 32 surveyed households. The Caboclos claim individual landownership to be more important than progress, in order to guarantee the continuity of their ancestral livelihoods. 
The Caboclos are multi-local and multi-functional. They farm cattle and water buffalo, using their milk to produce fine cheeses that the women sell on the streets and markets of nearby cities. Poultry, goats, sheep and pigs are reared both for subsistence and trade, but cattle and buffalo are kept on the floodplains as a service provided to rich landowners, in a clear survival strategy, because during the rainy season they either migrate to Santarém or to higher ground farms, shifting their status from smallholders to employees. Large barges transport the cattle up and down the Amazon River and its tributaries, people and animals accompanying and respecting the water's seasonal rhythm. Doris Sayago and Luciana Machado called these environmentally harmonic ancestral livelihoods the "Amazon of the Rivers" [7].

\subsection{The motorways: paths to deforestation}

By contrast, there is a more recent "Amazon of the Roads". The complexity of this second study area required more research time. For a decade now we have been exploring the subject $[2,5]$. As far as current the contribution is concerned, in 2008 fieldwork has targeted Brazil's highest ranking authorities and recent planning strategies, plus the evolution of transgenic seeds research. Additional fieldwork included ten in-depth interviews that involved soybean producers, totalling 60 informants, 37 of which were household farmers, both Caboclo smallholders from the Amazon River margins (32) and Central-Western and Southern immigrants settled along the motorways (5), who are credit-favoured, educated and modern entrepreneurs.

Agribusinesses settled within the former Amazon Rainforest area have been based either on the illegal appropriation of plots, or the eviction of smallholders and family farmers. Over the intended area for vegetable or animal farming, chemicals are thrown by plane, and then heavy machinery is used for tillage, whilst the noble woods are logged. Extensive fertilization and generous pesticides are necessary because mono-cultivation favours plagues and diseases. In 2007, agricultural commodities originating in the LBA amounted to $16 \%$ of national production, whereas soybean production had the largest share. In fact, if the surface occupied by grain and oilseeds totalled 36,335,844 hectares, soybeans alone covered 20,518,535 hectares of the countryside, 9,454,765 of which were located in LBA states. Whenever and wherever there are roads, soy follows suit. Brazil produced 58 million tons and the Amazon Region alone harvested 1,079 thousand tons of soybeans in 2007 [8].

About $90 \%$ of LBA areas are seeded with genetically modified species (GMS) that contain the Roundup Ready of Monsanto, further adapted by Embrapa Soy (the Brazilian public transgenic soy research unit) to the special heat and humidity conditions experienced in the LBA. The Tracajá variety dominates the Pará state, in particular alongside the BR-163, the so-called "Soybean Road". The yield is the highest in the country $-3,070 \mathrm{~kg}$ per hectare. The process has been increasing in the last two years (2006/07 and 2007/08) and Asian originated soybeans diseases have obliged the government to impose a 
four to six month sanitary void after each crop. New deforestation trends became imperative in order to get new farming spaces, incorporated because they constitute cheap uncontaminated soils.

Bordering the motorways, deforestation typology following the Second World War comprises four categories within the LBA:

1) Linear deforestation, so-called fish bone deforestation, is registered along the main road axes, in particular the Trans-Amazon;

2) Radial polarised deforestation is based on a rural pole city settled within the LBA, as is the case with Altamira, which is located beside the Trans-Amazon road;

3) Scattered deforestation has been registered all over the LBA and is usually associated with timber extraction, which is mostly illegal;

4) Continued deforestation, as displayed in Figure 4, a remote sensing imagery work dated August 2003. It started as type 1 and then evolved to type 2 , whereas wave spreading occurs near rural pole cities. The process moved northwards alongside the BR-163, from Cuiabá, Mato Grosso's capital city to Santarém, Pará [2,9].

Introduced in 1908, together with the Japanese community of immigrants, soybeans quickly conquered Southern Brazilian soils where they rotated with corn and were mostly used to feed cattle. During the 1960s and 1970s they migrated to Central-Western Brazilian areas, along with farming land hungry entrepreneurs stimulated by public colonisation programmes, which were heavily subsidised. It was only by the end of the 1980 s, however, that heat resistant varieties developed by science made it possible for the expansion of this formerly temperate climate crop to tropical climate regions, such as the NorthEastern and Northern Brazilian states. Currently, soybean ventures are based on bio-fuel production necessities, the future of the remaining rainforests being dependent on technocratic choices, supposedly environmentally friendly, made far away in global cities.

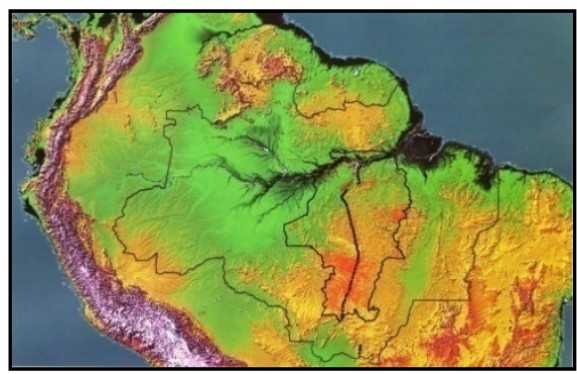

Figure 4: Satellite imagery showing the deforestation path along the Santarém-Cuiabá Road (BR-163), dated August 2003 (Carneiro [9]). 


\section{Conclusions}

The Amazon Rainforest is an exceptional hydrographical space, unique in its location atop the Equator and running parallel to it. The preservation of tropical forest biogenetic richness and the river's bounteous potential for life is a challenge and an excellent opportunity to prove the superior ingenuity of human kind [10]. Evidence suggests that climate change is increasing weather risks and affecting smallholder production worldwide. This is not the case with Caboclo communities, though. Fiercely adapted to seasonal floods, capable of respecting the capricious water rhythm, local peasants farm the Amazon River floodplains during the dry season, fish for subsistence and cash, raise their own poultry and small mammals, service cattle and water buffalo for landlords and rich traders and extract food and medicine from the forests without damaging the trees. The diversity of Caboclo livelihoods and their competent functionality on multiple tasks and jobs is a warranty of both household income and food security.
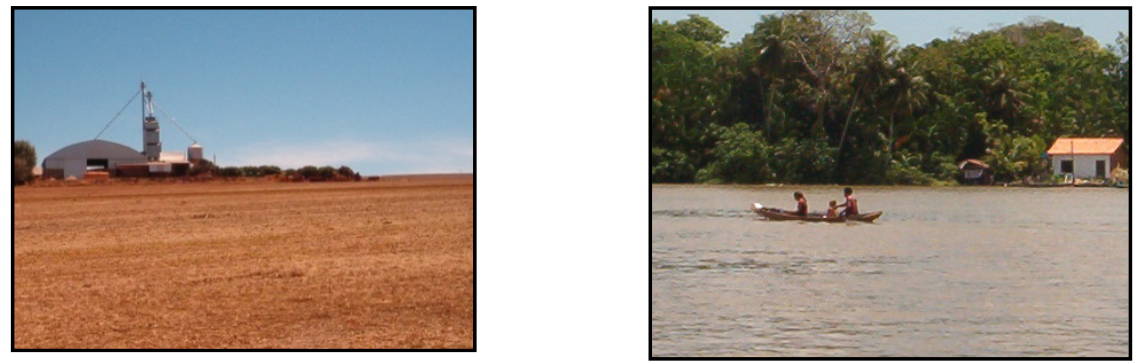

Figure 5: The "Amazon of the Roads" (Soybeans farm, 2008) versus the "Amazon of the Rivers" (Lower Amazon Igarapé, 2005).

Ancestral farming systems are not cherished in developed countries and they are even denied by some developing economies, Brazil being no exception. Science and modern technologies are used to control the forces of nature and stimulate economic advancement of peoples. This conception of modernity and progress collides with traditional practises that consume no technological products or chemical inputs. Moreover, the sheer necessity to produce and export large amounts of meat, grain, oil and fodder, added to the growing demand for renewable energy sources that might replace the limited fossil fuels, greatly encourages soy, corn, and sunflower as alternative crops for production in tropical regions. Commodity prices have been driven up, generating biofuel booms all over the globe, highly specialised, capital-intensive mono-cultivation forms that are soil hungry and will thus ultimately deforest the remainder of the natural ecosystems (Fig. 5). The collection of local seeds, local food and ancestral farming traditions from the Amazon River floodplains is therefore imperative before the announced death of the last tropical rainforest. Will Noah's Ark depart from the Amazon River's banks? 


\section{References}

[1] Ryder, R. and Brown, L.A. Urban-System evolution on the frontier of the Ecuadorian Amazon. The Geographical Review, 90 (4), pp. 511-535, 2000.

[2] Madaleno, I. M. Amazon Rainforest Current Threats: The Soybean Boom. Deutscher Tropentag 2008, 4pp., 2008 http://www.tropentag.de/2008/ abstracts/full/296.pdf

[3] MMA. Plano Amazônia Sustentável: Directrizes para o desenvolvimento sustentável da Amazônia Brasileira. Ministério do Meio Ambiente, Brasília, 2008.

[4] Ab'Saber, A.N. Amazônia, do Discurso à Praxis. Universidade de S. Paulo, S. Paulo, 2004.

[5] Madaleno, I.M. Urban Agriculture in Belém, Brazil. Cities, 17 (1), pp. 73 77, 2000.

[6] Carvajal, F.G. Relación del Nuevo Descubrimiento del Famoso Río Grande. Maderuelo, R.D. (ed.) La Aventura del Amazonas. Dastin, Madrid, pp. 31-88, 2002 (first edited in 1542).

[7] Sayago, D. and Machado, L. O Pulo do Grilo: O INCRA e a questão fundiária na Amazônia. Sayago, D., Tourrand, J-F. and Bursztyn, M. (ed.) Amazônia, Cenas e Cenários. Universidade de Brasília, Brasília, pp. $217-$ 235, 2004.

[8] Gazeta. Brazilian Soybean Yearbook. Gazeta Santa Cruz, Santa Cruz do Sul, 2007.

[9] Carneiro, A. Amazônia Revelada: os descaminhos ao longo da BR-163. CNPq, Brasília, 2005

[10] Monteiro, S. and Kaz, L. Amazonia, Flora and Fauna. Livroarte, Rio de Janeiro, 1997. 